\title{
THYMUS COLDEI PÎNZARU SP. NOVA (LAMIACEAE) IN THE FLORA OF THE REPUBLIC OF MOLDOVA
}

\author{
Pavel PÎNZARU ${ }^{1,2}$ \\ 1 "Alexandru Ciubotaru” National Botanical Garden (Institute), Chișinău - Republic of Moldova. \\ ${ }^{2}$ Tiraspol State University, Chișinău - Republic of Moldova. \\ E-mail: p_panzaru@yahoo.it
}

\begin{abstract}
The paper describes a new species for science - Thymus coldei Pînzaru sp. nova, occurring on Middle Sarmatian limestones, in the Republic of Moldova.
\end{abstract}

Key words: Thymus, Lamiaceae, new species, Republic of Moldova.

\section{Introduction}

Four species of the genus Thymus L. were identified in the cliff area of the Republic of Moldova: T. pannonicus All. [GHEIDEMAN, 1986], T. marschallianus Willd. [GHEIDEMAN, 1986; NEGRU, 2007], T. moldavicus Klokov et Des.-Shost. [GHEIDEMAN, 1986; NEGRU, 2007; PÎNZARU, 2020] and $T$. roegneri K. Koch [PÎNZARU \& CANTEMIR, 2018; PÎNZARU, 2020], the last 2 species occur only on limestone slopes. The floristic research on species of the genus Thymus L. was continued by the author in order to describe them for the flora of Bessarabia.

This article highlights and describes a new species for science - Thymus coldei Pînzaru sp. nova, detected in the Middle Sarmatian limestone area in the Republic of Moldova.

\section{Materials and methods}

The floristic research was carried out by the author in the years 2003, 2005, 2009, 20152021 on the calcareous hills from the basins of the Dniester river and the Prut river. Twenty-one specimens of Thymus coldei Pînzaru sp. nova have been collected and botanized, the exsiccatae are stored in the Herbarium of the "Alexandru Ciubotaru" National Botanical Garden (Institute) in Kishinev [CHGB], in the Herbarium of "Anastasie Fătu" Botanical Garden of Iași [IAGB 47713] and in the Herbarium of the botanist Pavel Pînzaru at the Tiraspol State University (based in Kishinev) [CHUST-PP]:

- Glodeni district, Cobani commune, on rendzina soil, rich in calcareous gravel, of the Middle Sarmatian stage, 10 VI 2020, P. Pînzaru [CHUST-PP 2923];

- Floreşti district: Ţîra village in Ghindeşti commune, on Middle Sarmatian limestones, on the left bank of the Răut river, 20 V 2015, P. Pînzaru [CHUST-PP 2916];

- Şoldăneşti district: Rogojenii Vechi village in Rogojeni commune, on Middle Sarmatian limestones, in the valley of the Răut river, 28 VII 2003, P. Pînzaru [Paratype: CHUST-PP 2923, 1894; CHGB 239638]; 21 V 2009, P. Pînzaru [CHUST-PP 2913; CHGB 239634]; 
- Orhei district: Orhei city towards Păhărniceni commune, on rendzina soil, rich in limestone gravel of the Middle Sarmatian stage, on the left bank of Răut river, 12 V 2009, P. Pînzaru [CHUST-PP 2917]; Piatra commune, on Middle Sarmatian limestones, on the left bank of Răut river, 10 VI 2015, P. Pînzaru [CHUST-PP 2914, 2915; CHGB 239636]; Păhărniceni commune, on Middle Sarmatian limestones, on the left bank of Răut river, 12 V 2009, P. Pînzaru [CHUST-PP 2918], 10 VI 2015, P. Pînzaru [CHGB 239639];

- Dubăsari district: Molovata commune towards Marcăuţi commune, on Middle Sarmatian limestones, on the right bank of Dniester river, 20 V 2016, P. Pînzaru [CHUST-PP 1896; CHGB 239637];

- Kishinev municipality: Goian village in Ciorescu commune, on rendzina soil, rich in calcareous gravel, of the Middle Sarmatian stage, on the left bank of the Ichel river, 19 V 2018, P. Pînzaru [CHUST-PP 2919]; Făureşti village in Ciorescu commune, on Middle Sarmatian limestones, on the left bank of the Ichel river, 21 VI 2020, P. Pînzaru [CHGB 239635], 07 VI 2021, P. Pînzaru [CHUST-PP 2924]; Ciorescu commune, on Middle Sarmatian limestones, in the valley of the Ichel river, 08 VI 2021, P. Pînzaru [Holotype: CHGB 239640], 21 VI 2020, P. Pînzaru [Isotype: CHGB 239641], 08 VI 2021 P. Pînzaru [CHUST-PP 2920], Cricova town, Chişinău municipality, on rendzina soil, rich in calcareous gravel, of the Middle Sarmatian stage, in the valley of the Ichel river, 21 VI 2020, P. Pînzaru [CHUST-PP 2921].

Eleven exsiccatae of Thymus moldavicus Klokov \& Des.-Shost., collected by the author from the districts of the Republic of Moldova, were examined as comparative material:

- Criuleni district, Maşcăuţi commune on the border with Morovaia village, on Middle Sarmatian limestones, on the left bank of the Răut river, 13 VII 2018, P. Pînzaru [CHGB 239643, 239644], 22 VI 2020, P. Pînzaru [CHUST-PP 869], 13 VII 2020, P. Pînzaru [CHUSTPP 1874]; Maşcăuţi commune, on Middle Sarmatian limestones, on the right bank of the Răut river, 23 V 2018, P. Pînzaru [CHUST-PP 871, 872];

- Orhei district, Butuceni village in Trebujeni commune, on Middle Sarmatian limestones, on the left bank of the Răut river, 23 VI 2020, P. Pînzaru [CHGB 239633; CHUSTPP 870]; Morovaia village in Trebujeni commune, on Middle Sarmatian limestones, on the left bank of the Răut river, 23 VI 2020, P. Pînzaru [CHGB 239642];

- Grigoriopol district, Taşlîc commune, on Middle Sarmatian limestones, on the right bank of the Taşlîc river, 21 VIII 2018, P. Pînzaru [CHGB 239645]; Butor commune, on Middle Sarmatian limestones, on the left bank of Dniester river, 21 VIII 2018, P. Pînzaru [CHGB 239646].

The identification of the plants was performed according to the classical comparativemorphological method, using the keys for identifying the species of the genus Thymus L. [JALAS, 1972; MENITSKY, 1978; GHEIDEMAN, 1986; DOBROCZAJEVA \& al. 1999; NEGRU, 2007; SÂRBU \& al. 2013; KNYASEV, 2015]. We examined the exsiccatae of the genus Thymus L. from the collection of the Herbarium of the "Alexandru Ciubotaru" National Botanical Garden (Institute), Kishinev, and of the species Thymus glabrescens Willd. (species that shares some similar characteristics with the new species) from the collections of the Herbaria of the "Anastasie Fătu" Botanical Garden [IAGB] and of the "Alexandru Ioan Cuza" University of Iaşi [I].

The botanical illustration was drawn by the illustrator Petru Leca, in consultation with the author, based on the selected original material. 


\section{Results and discussions}

As a result of the floristic research carried out on the species of the genus Thymus L. occurring in the cliff areas of the Republic of Moldova, a new species for science was identified - Thymus coldei Pînzaru sp. nova, described below. Thymus coldei plants, during the flowering stage, begin to develop repent stems, which continue to grow until autumn, forming serial clusters of leaves, which will produce flowering branches in the following year (Figure 1). The sterile repent stems, in some places, at the internodes, develop adventitious roots, favouring vegetative propagation. The fruiting branches die after dissemination (Figure 2).

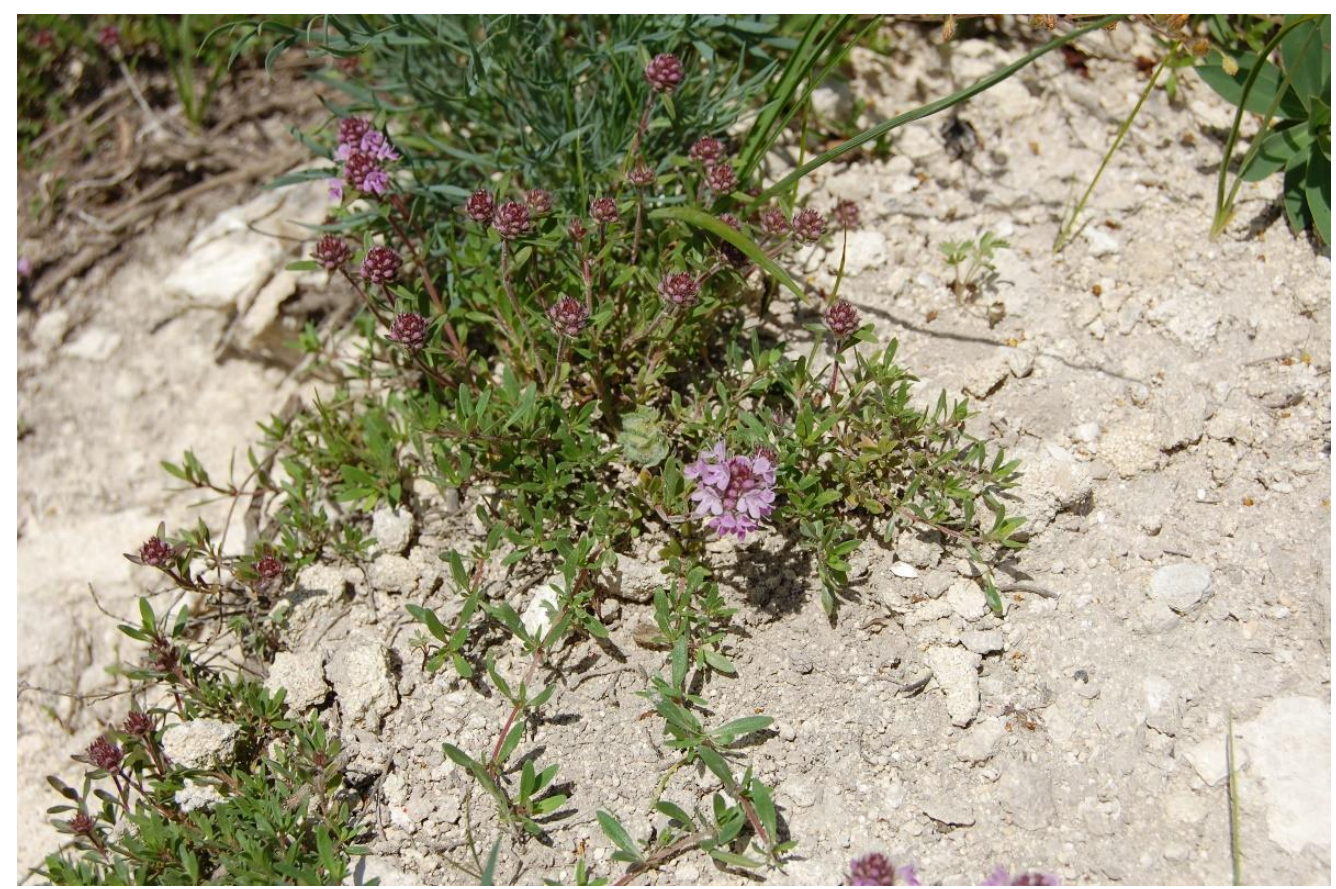

Figure 1. Thymus coldei Pînzaru sp. nova, 08 VI 2021,

Ciorescu commune, Kishinev municipality

Thymus coldei Pînzaru sp. nova - Coldea thyme - Figure 1-4

Lemon-scented plants. Stems repent, long, with erect or ascending flowering branches towards the tips; during the flowering stage, the plant develops long, sterile stems, which take root. Flowering branches 2-7 (-12) cm tall, arranged in series; pubescent around: in the first half - evenly pubescent, in the second half (towards the top) on sides with short hairs, $0.5 \mathrm{~mm}$, oriented downwards, and on the edges with twice longer, upright hairs. The lower leaves are lanceolate or slightly spatulate, 3-5 mm long, 1-3 mm wide, the middle ones - slightly longer than the upper ones, linear-lanceolate, 10 to $15 \mathrm{~mm}$ long and $1.5-2.5 \mathrm{~mm}$ wide, petiolate to subsessile, glabrous on both sides, at the base, with few cilia on margins. The inflorescences are usually heads, rarely with 1-2 whorls. The flowers are borne on $\pm 2 \mathrm{~mm}$ long peduncles. The bracts are ovate, ovate-elongated, as long as the calyx or shorter, with well-defined veins. The calyx is $3 \mathrm{~mm}$ long, on the ventral side densely pubescent, upright hairs. The upper teeth of the calyx are slightly elongated in shape, ciliated. The corolla is $6 \mathrm{~mm}$ long, pink, pubescent on the 
outside, the upper lip is slightly emarginate, the lower lip - with 3 lobes almost equal in size, spotted at the base. There are 2 stamens under the upper lip and 2 exserted ones. The stigma is bifurcated, exserted. The seeds are rounded, ovoid, 0.7-0.8 mm long, brown.

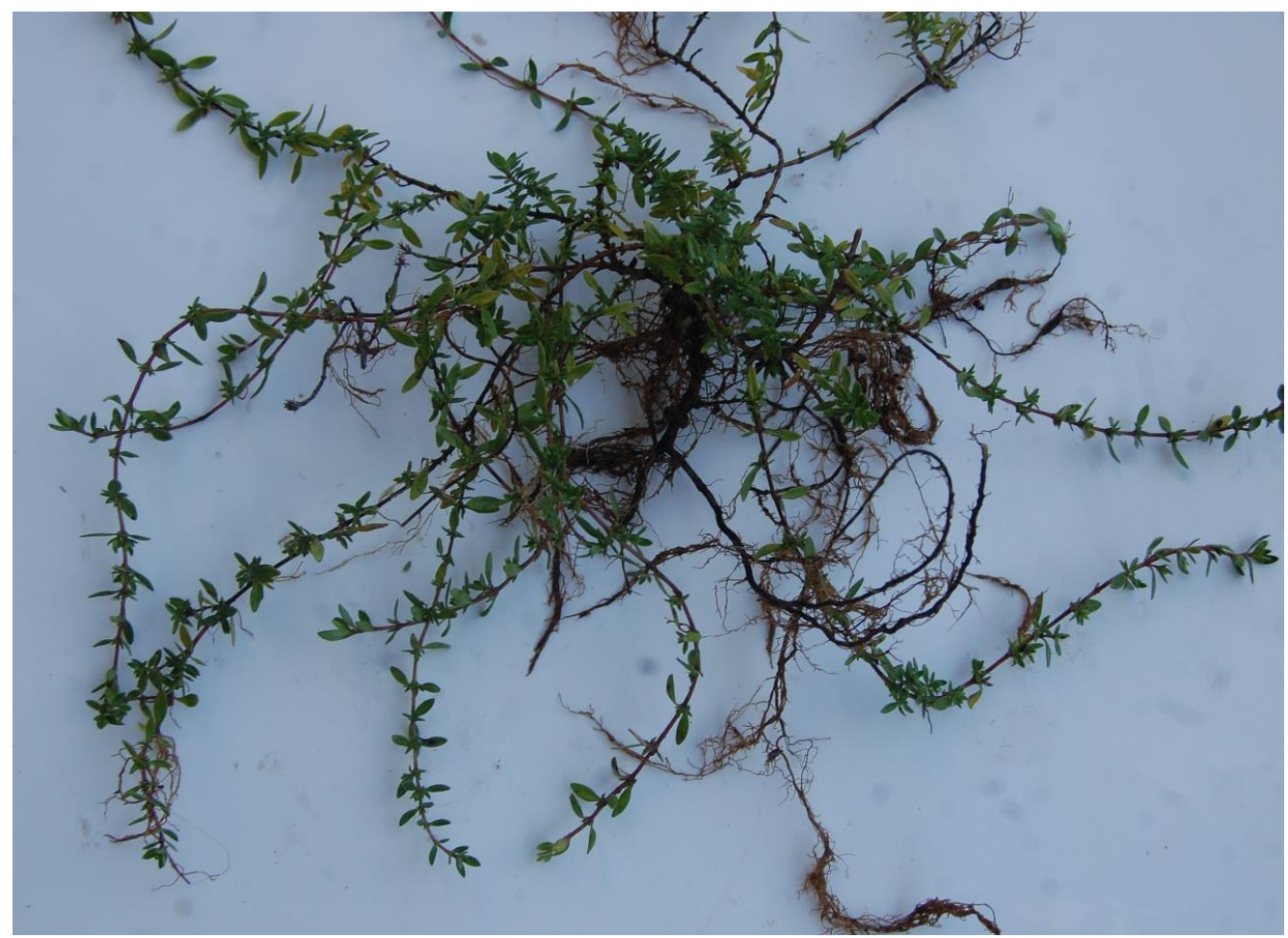

Figure 2. Thymus coldei Pînzaru, 24 VIII 2021, Ciorescu commune, Kishinew municipality

H o 1 o t y p e: Republic of Moldova, Ciorescu commune, Kishinev municipality, on Middle Sarmatian limestones, on the left bank of the Ichel river, collected on 08 VI 2021, P. Pînzaru, determined on 10 VI 2021 [CHGB 239640].

I s o t y p e: Republic of Moldova, Ciorescu commune, Kishinev municipality, on Middle Sarmatian limestones, on the left bank of the Ichel river, collected on 21 V 2020, P. Pînzaru, determined on 10 VI 2021 [CHGB 239641].

P a r a t y p e: Republic of Moldova, Rogojenii Vechi village, Şoldăneşti district, on Middle Sarmatian limestones, in the valley of the Răut river, collected on 28 VII 2003, P. Pînzaru, determined on 10 VI 2021 [CHUST-PP 2923]. 


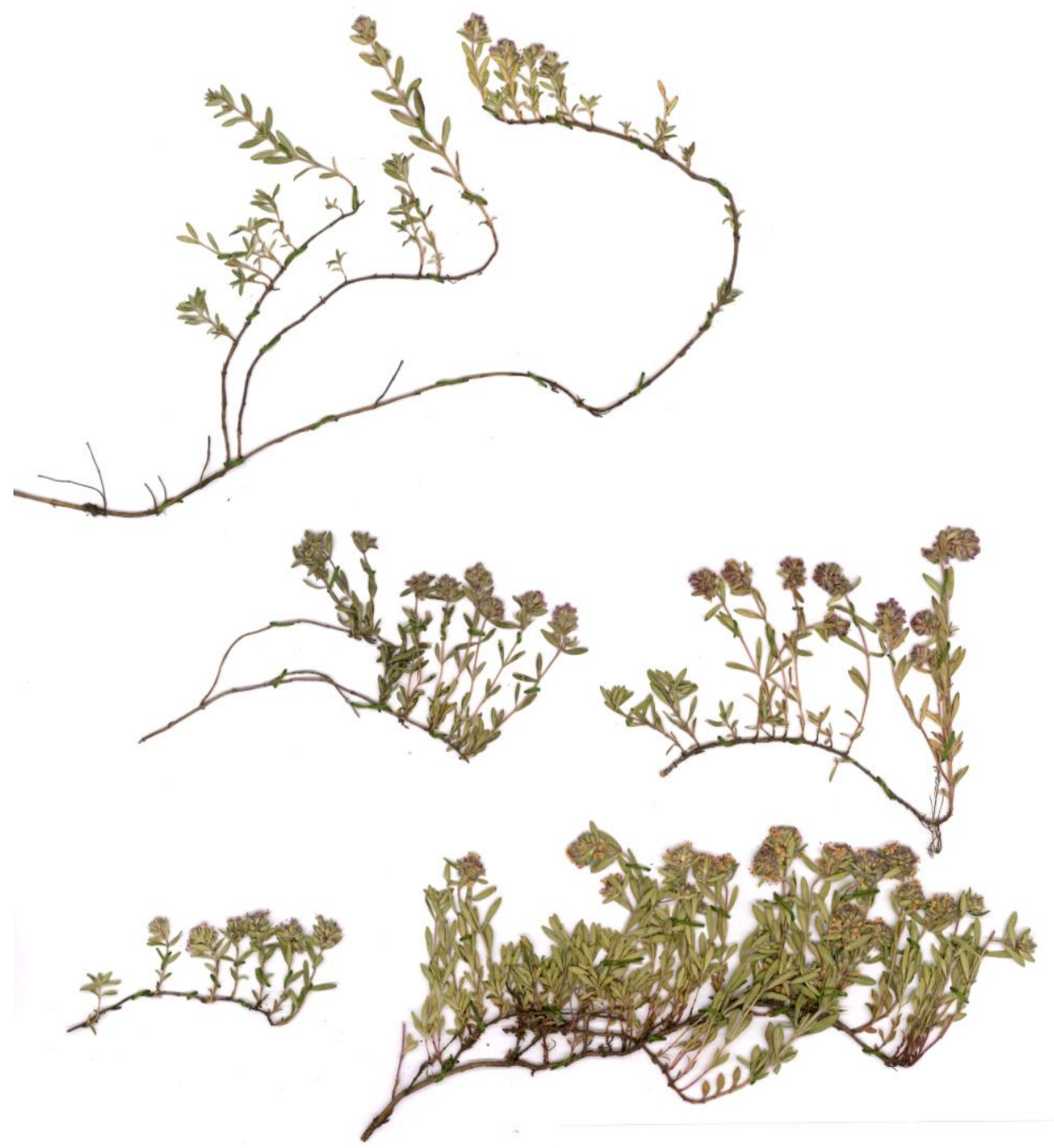

HOLOTYPUS

Thymus coldei Pînzaru sp. nova

Grădina Botanică Națională (I)

10 VI 2021 Teste Pavel PÎNZARU „Al. Ciubotaru”,Chișinău

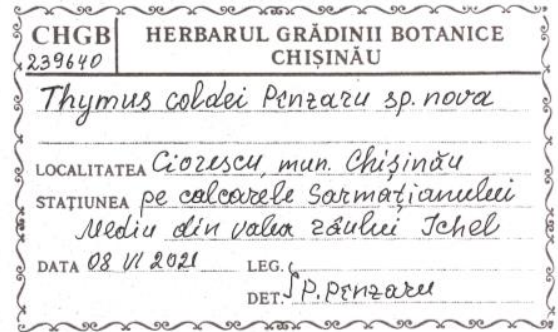

Figure 3. Holotype of Thymus coldei Pînzaru (CHGB 239640) 


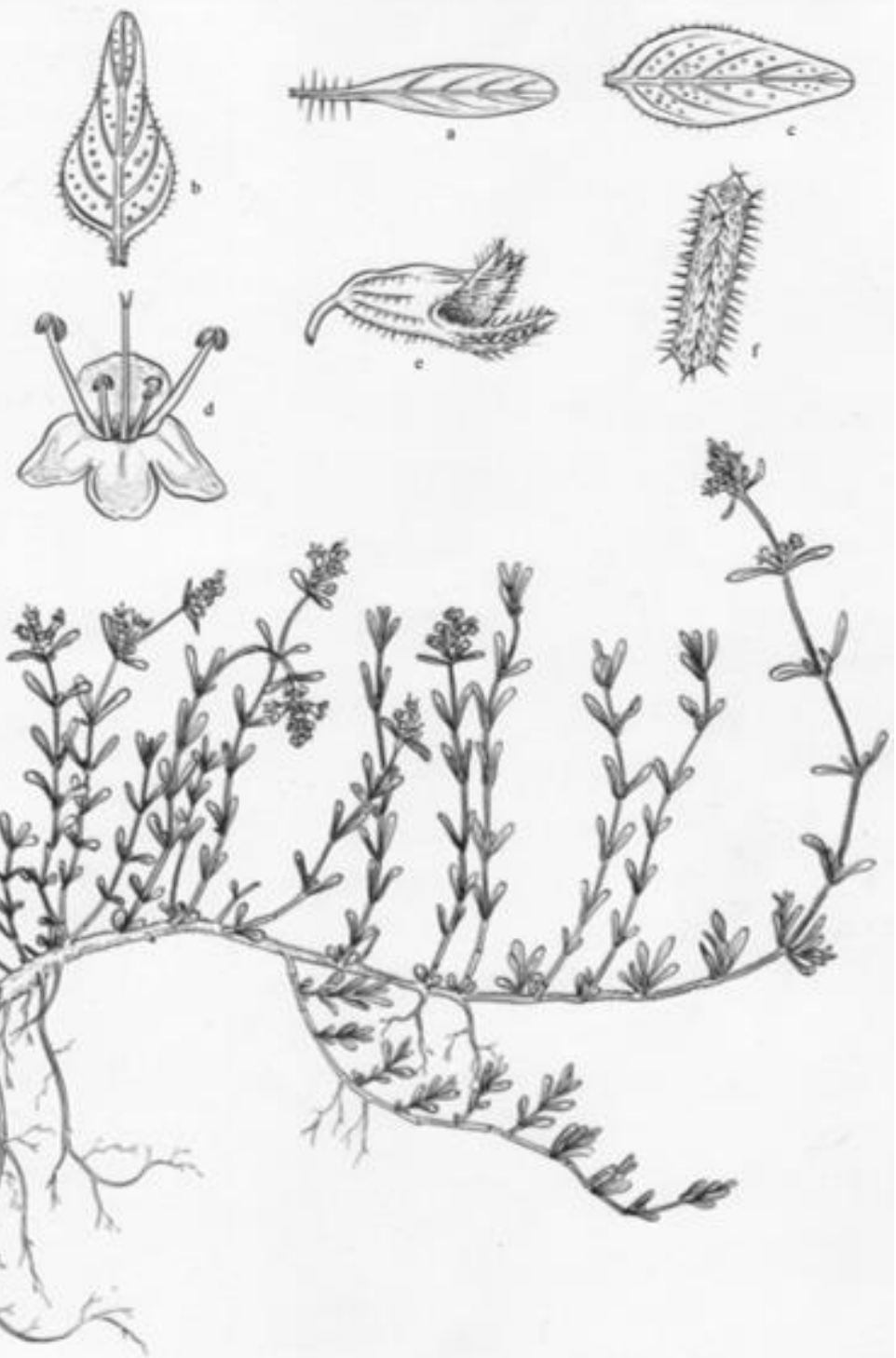

Figure 4. Thymus coldei Pînzaru - a. leaf; b, c. bracts; d. flower; e. calyx; f. segment of a flowering branch below the inflorescence

Affinity. The new species is similar to Thymus moldavicus Klokov et Des.-Shost, having repent, long stems, head inflorescences, bracts of different shape than the upper leaves, calyx with ciliated teeth, but it differs in the pubescence of the flowering branches - on the second half, on sides - with short, adpressed, downwards oriented hairs, and on edges - with twice longer, upright (not flowering branches equally pubescent all around, with short, downwards oriented hairs), the upper teeth of the calix are longer that wide (not upper teeth of 
Pavel PÎNZARU

the calix of almost equal length and width), the plants smell like lemon and not otherwise. Both species grow on Sarmatian limestones, but separately one from another. Another species with similar habit is Thymus glabrescens Willd., but it differs from the species T. coldei in the shape of the leaves - they become larger from the base towards the tip of flowering branches, and the bracts are of the same shape as the leaves and do not have a lemon-like smell.

Biological and ecological peculiarities. Chamaephyte species, blooms in June-July, xerophyte, calcicole. It propagates by seeds and vegetatively. It is a melliferous, ornamental, spicy (used to prepare herbal tea) plant. It grows on bare limestones of the Middle Sarmatian stage or on rendzina soils, rich in calcareous gravel, it is characteristic of the vegetation in the alliance Genisto tetragonae-Seselion peucedanifolii P. Pânzaru 1997 (Figure 5). It grows at 50$110 \mathrm{~m}$ altitude.

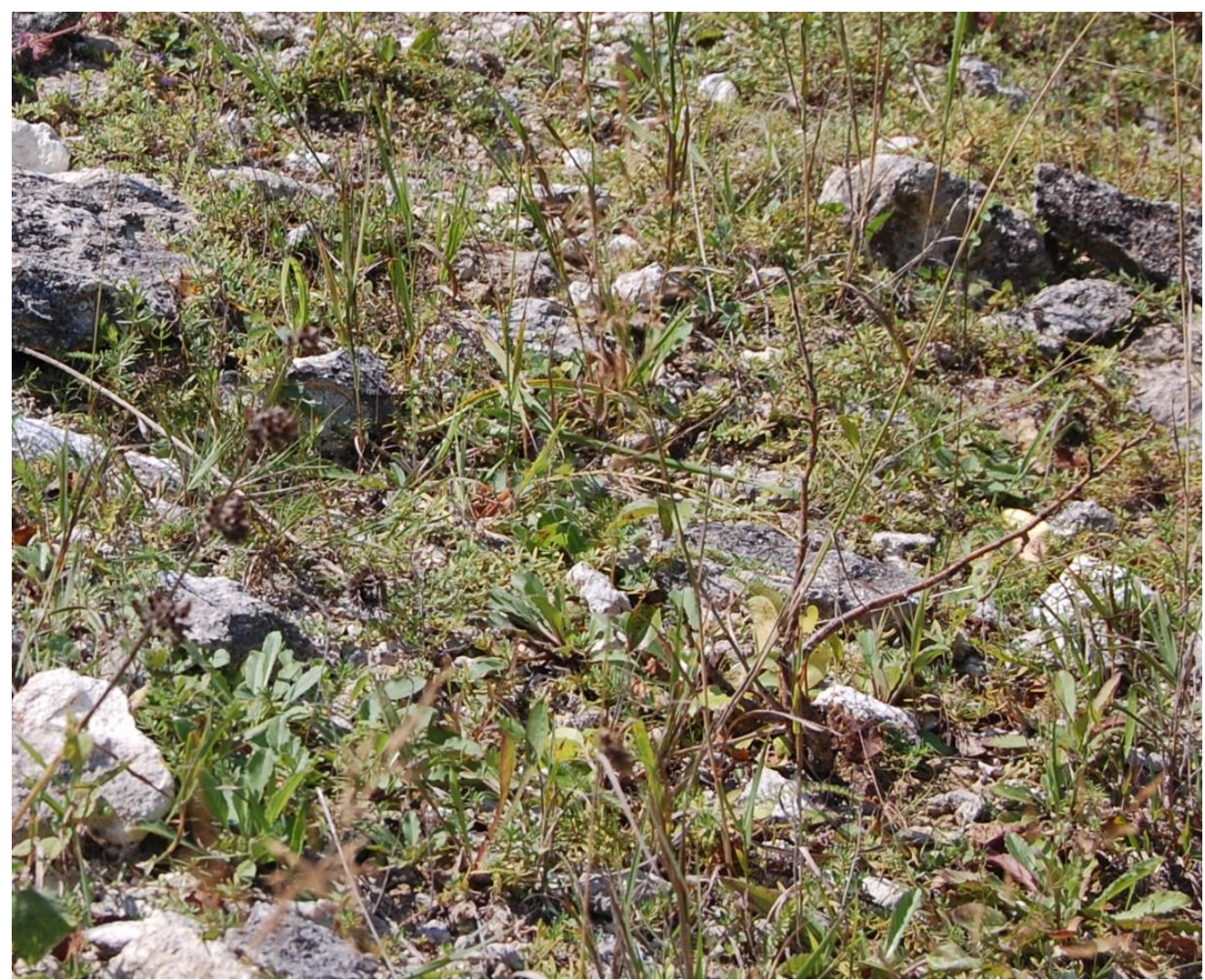

Figure 5. Thymus coldei Pînzaru in its natural habitat, Ciorescu commune, 24 VIII 2021

Distribution in the districts of the Republic of Moldova (Figure 6): Glodeni (Cobani), Floreşti (Ţîra), Şoldăneşti (Rogojenii Vechi), Orhei (Orhei, Piatra, Păhărniceni), Dubăsari (Molovata), Kishinev municipality (Ciorescu, Făureşti, Goian, Cricova).

Limiting factors. Specific habitat. Limestone extraction from open quarries and irrational collecting lead to a reduction in the areas of distribution of the species. 
Conservation status. It is territorially protected within the area of the "Mâgla Rock" Geological and Paleontological Nature Monument, near Piatra commune, Orhei district.

Protection measures. Prohibition of limestone extraction from open quarries, the inclusion of the species in the List of species protected by the state and in the Red Book of the Republic of Moldova, in the vulnerable category (VU), the inclusion in the Network of Protected Areas of the canyon "Rogojenii Vechi” found near Rogojenii Vechi village, Şoldăneşti district, and the limestone hills in the valley of Ichel river (near Ciorescu commune and Făureşti and Goian villages).

The species has been named in honour of the corresponding member of the Romanian Academy Gheorghe COLDEA, Cluj-Napoca.

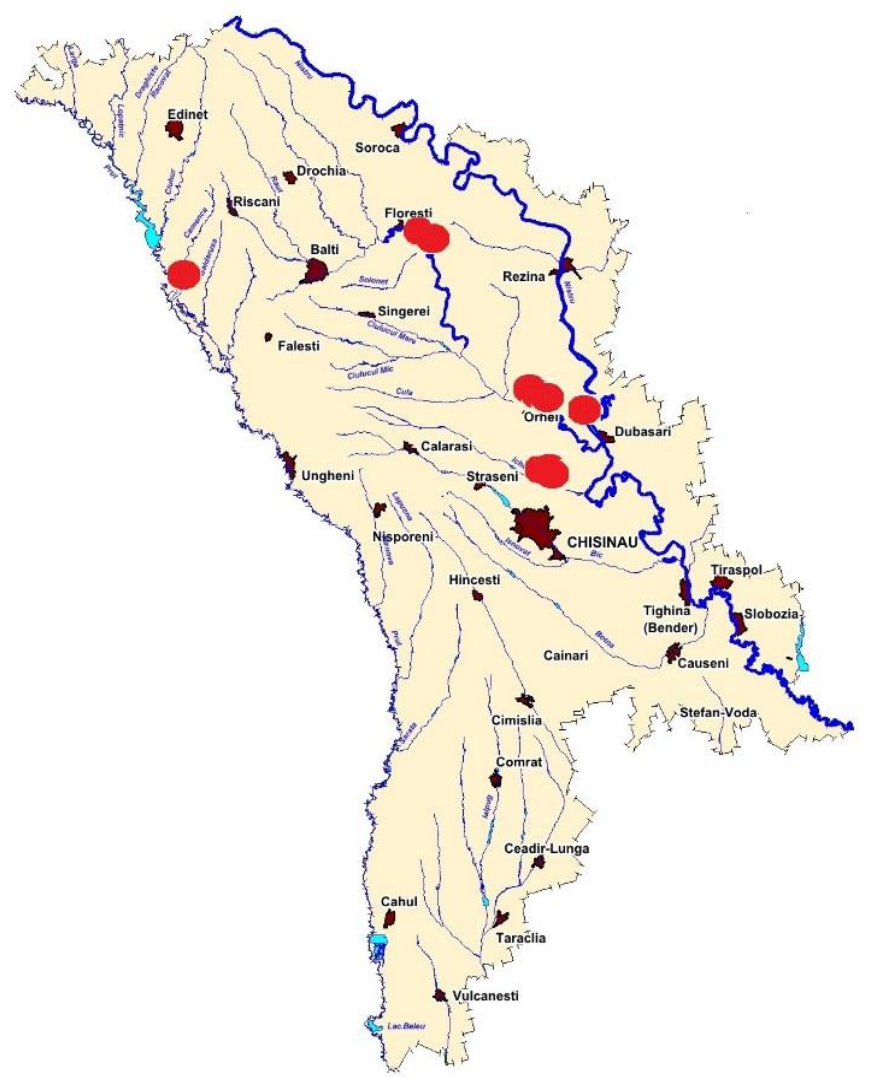

Figure 6. Locations of Thymus coldei Pînzaru in the Republic of Moldova

\section{Conclusions}

Thymus coldei Pînzaru is an endemic species of Middle Sarmatian limestones, xerophyte, vulnerable, therefore it is necessary to undertake protection measures, namely, to stop the extraction of limestone from open quarries in the valley of the Ichel river, in the sector Cricova - Goian, in Kishinev municipality. 
The research was supported by the NARD through the project "Research and conservation of vascular flora and macromycobiota of the Republic of Moldova", 20.80009.7007.22 (contract Nr. 71/PS/2020).

\section{References}

DOBROCZAJEVA D. N., KOTOV M. I., PROKUDIN YU. N. \& al. 1999. Opredelitel' vysših rastenij Ucrainî. Kiev: $546 \mathrm{pp}$.

GHEIDEMAN T. S. 1986. Opredelitel' vysših rastenij Moldavskoj SSR. Kišinev: Ştiinţa, 638 pp.

JALAS J. 1972. Thymus L. In: TUTIN T. G. \& al. (eds.). Flora Europaea. Vol. 3. Cambridge: Cambridge University Press. 3: 172-182.

KNYASEV M. S. 2015. The survey of east European and Ural species of the genus Thymus L. (Lamiaceae). Journal of Botany. L. 100(2): 114-141. (In Russian).

MENITSKY G. L. 1987. Genus Thymus L. In: FEDOROV An. A. (eds.). Flora partis europaeae URSSS. L.: Nauca. 3: 191-204. (In Russian).

NEGRU A. 2007. Determinator de plante din flora Republicii Moldova. Chişinău: Universul. 391 pp.

PÎNZARU P. 2020. Plante rare de stâncării din Republica Moldova. Chişinău: Tipogr. UPS “Ion Creangă”: 330 pp.

PÎNZARU P. \& CANTEMIR V. 2018. Floristic notes in Bessarabia No. 165-200. Journal of Botany. 10, 2 (17): 32-41.

SÂRBU I., ŞTEFAN N. \& OPREA A. 2013. Plante vasculare din România. Determinator ilustrat de teren. Bucureşti: Edit. Victor B Victor: 1317 pp.

How to cite this article:

PÎNZARU P. 2021. Thymus coldei Pînzaru sp. nova (Lamiaceae) in the flora of the Republic of Moldova. J. Plant Develop. 28: 175-183. https://doi.org/10.47743/jpd.2021.28.1.890 